\title{
Hypoxia Induces Dysregulation of Lipid Metabolism in HepG2 Cells via Activation of HIF-2 $\alpha$
}

\author{
Risheng Cao ${ }^{a}$ Xiaodan Zhao \\ Xiqiao Zhou Hongjie Zhang $^{\text {a }}$ Ruihua Shia \\ aDepartment of Gastroenterology, First Affiliated Hospital of Nanjing Medical University, Nanjing, \\ ${ }^{b}$ Department of Geriatric Medicine, Suzhou Municipal Hospital, Suzhou, China
}

\section{Key Words}

HIF-2 $\bullet$ HepG2 • Fatty acid metabolism • Cholesterol metabolism

\begin{abstract}
Background: Hypoxia is a risk factor for non-alcoholic fatty liver diseases, leading to permanent imbalance of liver lipid homeostasis and steatohepatitis. The current study examined the effect of HIF-2 $\alpha$, an oxygen-sensitive heterodimeric transcription factor, on hypoxia-induced dysregulation of lipid metabolism in HepG2 cells. Methods: Studies were conducted in C57BL/6 male mice and human HepG2 cells under hypoxic conditions, transfected with HIF-2 $\alpha$-targeted shRNA. The mRNA and protein expressions of key genes relevant to lipid metabolism were determined via RT-qPCR and western blot, respectively. Intracellular lipid accumulation was determined by Nile red, filipin staining and quantitative assay kits. Results: HIF- $2 \alpha$ protein was quantified in both HepG2 cells and C57BL/6 mice under hypoxic conditions. Intracellular lipid accumulation and increased lipid levels induced by hypoxia were significantly reduced by silence of HIF- $2 \alpha$ expression, associated with reversed expression of $A B C A 1$ and $A D R P$, key genes involved in cholesterol excretion and fatty acid uptake respectively. However, HIF$2 \alpha$ had no effect on enzymatic activity and expression of key genes involved in fatty acid $\beta$-oxidation or cholesterol metabolism. Conclusion: Inhibition of HIF-2 $\alpha$ protein reversed lipid metabolism dysregulation induced by acute hypoxia in HepG2 cells, which suggested that HIF- $2 \alpha$ signaling may be relevant to oxygen-dependent lipid homeostasis in the liver.
\end{abstract}

R. Cao and X. Zhao contributed equally to this work. 


\section{Cellular Physiology and Biochemistry}

Cell Physiol Biochem 2014;34:1427-1441

DOI: 10.1159/000366348

Published onIIne: October 06, 2014

Cao et al.: HIF-2 $\alpha$ Regulates Lipid Metabolism

\section{Introduction}

Oxygen is crucial to the process of metabolism. A state of hypoxia, or lack of adequate oxygen, activates a variety of complex pathways at both the cellular and organ level to reinstate oxygen homoeostasis. The liver is essential to metabolism, and is extremely sensitive to low-oxygen conditions. Lipid accumulation in the blood vessels and other tissues of the liver leads to an insufficient blood supply to hepatocytes and lipid peroxidation, setting up a hypoxic microenvironment; prolonged hypoxia can promote uncontrolled lipid accumulation [1, 2]. The liver's metabolic functions include lipid biosynthesis, uptake, catabolism, and reverse cholesterol transport. Lipid biosynthesis in the liver is regulated by sterol regulatory element-binding proteins (SREBPs), a family of transcription factors that include the isoforms SREBP-1a, SREBP-1c, and SREBP-2 [3]. SREBP-1a is a potent activator of all SREBP-responsive genes, including those that mediate the synthesis of fatty acids, cholesterol, and triglycerides, whereas SREBP-1c preferentially regulates enzymes of fatty acid synthesis. Fatty acid synthase (FAS) is the principle target of SREBP-1c [4, 5]. SREBP-2 regulates cholesterol biosynthesis and uptake, in particular the low-density lipoprotein receptor (LDLR) [6, 7]. Another target of SREBP-2 is 3-hydroxy-3-methyl-glutaryl-coenzyme A reductase (HMGCR), the rate-limiting step and major control point of de novo cholesterol synthesis $[8,9]$.

Other genes important to lipid metabolism in the liver include adipose differentiationrelated protein (ADRP), which participates in fatty acid uptake.Carnitinepalmitoyltransferase$1 \alpha$ (CPT- $1 \alpha)$, a target of peroxisome proliferator-activated receptor alpha (PPAR- $\alpha$ ), controls mitochondrial fatty acid import [5]. Hydroxyacyl-CoA dehydrogenase (HADH) catalyzes the $\mathrm{NAD}^{+}$-dependent dehydrogenation step in fatty acid $\beta$-oxidation [10].

Cholesterol catabolism involves mainly the biodegradation of cholesterol to bile acids occurring in the hepatocyte endoplasmic reticulum, and begins with the transformation of cholesterol into 7-alpha-hydroxy cholesterol catalyzed by CYP7A1 (cytochrome P450 family 7 subfamily A polypeptide 1) [11-13]. Cholesterol clearance pathways are also mediated by members of the ATP-binding cassette (ABC) transporter family. An example is ABCA1 (ABC subfamily A member 1 ), which participates in transport of cholesterol in the hepatocyte to lipoprotein receptors and the formation of HDL cholesterol $[14,15]$. ABCG5 and ABCG8 (ABC subfamily $\mathrm{G}$ members 5 and 8, respectively) regulate the excretion of liver cellular cholesterol into bile $[16,17]$.

The hypoxia-inducible factor (HIF) family of transcription factors has a central role in the main pathway associated with hypoxic stress $[18,19]$. They participate in tissue adaptive responses to hypoxia by regulating the expression of hypoxia-induced genes. allowing survival within a large range of reduced oxygen concentrations. The HIF family are heterodimers composed of one $\alpha$ subunit that is unstable in the presence of relatively high levels of oxygen (above 5\%), and one constitutively expressed $\beta$ subunit (or ARNT [aryl hydrocarbon receptor nuclear translocator]). Mammals possess three HIF isoforms, HIF-1, HIF-2, and HIF-3.

Under normoxic conditions, HIF- $\alpha$ subunits are targeted for proteasomal degradation by the Von Hippel-Lindau (VHL) tumor suppressor (Pvhl) catalyzed by oxygen-dependent prolyl hydroxylase domain (PHD) proteins (PHD 1, 2 and 3). Under hypoxic conditions, HIF- $\alpha$ subunits are stabilized and translocate to the nucleus to activate transcription upon binding to hypoxia response elements located within regulatory elements of HIF-target genes.

HIF-2 $\alpha$, also known as EPAS1 (Homo sapiens endothelial PAS domain protein 1), HLF (HIF-like factor), HRF (HIF-related factor), or MOP2 (member of PAS superfamily 2), was first discovered by Tian et al. in 1997 [20]. Recent studies have reported that many cellular processes such as angiogenesis, erythropoiesis, energy metabolism, cell migration, and tumor invasion are influenced by HIF- $2 \alpha$. Since oxygen consumption in mitochondria seriously influences fatty acid oxidation during hypoxia, it is conceivable that lipid metabolism should be regulated through activation of HIFs. However, the effects of HIF- $2 \alpha$ and HIF- $1 \alpha$ on lipid metabolism have not been definitively determined. 


\section{Cellular Physiology and Biochemistry}

Cell Physiol Biochem 2014;34:1427-1441

DOI: $10.1159 / 000366348$

Published online: October 06, 2014

(c) 2014 S. Karger AG, Basel

www.karger.com/cpb

In certain cell types, the expression of PPAR $\alpha$ and the DNA-binding affinity of PPAR $\alpha$ were reduced during hypoxia, in a HIF-1 $\alpha$-dependent manner [21]. Moreover, HIF-1 $\alpha$ has been reported to induce the expression of HIG2, a lipid droplet protein involved in neutral lipid formation [22], and HIF-1 $\alpha$ was even considered a protective factor against alcoholic fatty liver [23]. In contrast, Rankin et al. [24] disclosed the importance of HIF-2 $\alpha$ rather than HIF- $1 \alpha$ in the regulation of lipid droplet formation and continuous lipid accumulation in VHL-deficient mouse liver. This conclusion was further supported by another study indicating that development of fatty liver disease in PHD2/3 knockout mice was under the control of HIF- $2 \alpha$ [25]. Considerable controversy remains regarding hepatic steatosis in HIF$2 \alpha$-deficient mice [26], and lipid accumulation stimulated by forced expression of HIF-1 $\alpha$ in mice [27].

Considering the controversies surrounding HIFs in lipid metabolism, it is important to understand all of the mechanisms of hypoxia-induced lipid dysregulation and clarify the roles of HIFs separately. In this study, we focused on whether HIF- $2 \alpha$ is associated with lipid metabolism under hypoxic conditions in cells of the human hepatoma cell line HepG2, and investigated the molecular processes activated within the cells.

\section{Materials and Methods}

C57BL/6 mouse liver ischemia-reperfusion (IR) model

The Ethics Committee of Nanjing Medical University approved this study. Six male C57BL/6 wildtype mice (age 10 weeks; 22-25 g) were purchased from Model Animal Research Center of Nanjing Medical University, Nanjing, China. The 6 mice were randomly apportioned to a control group or an ischemic-reperfusion (IR) group. Mice were anesthetized by intraperitoneal injection of $60 \mathrm{mg} / \mathrm{kg}$ sodium pentobarbital. The skin was disinfected with $1 \%$ iodine. The incision was mid-abdominal to allow for full liver exposure. For mice in the IR group, blood vessels were clamped with a non-invasive vascular clamp for one hour as described previously [28], which led to segmental (70\%) hepatic ischemia, and then the liver was reperfused for $6 \mathrm{~h}$ before tissues were harvested. Mice in the control group underwent the same procedure, but with no clamping of the blood vessels. The mice were euthanized by cutting the diaphragm and heart. Hepatic tissue was obtained and rapidly stored at $-70^{\circ} \mathrm{C}$ for future analysis.

\section{Cell culture}

Cells of the human hepatocellular carcinoma cell line HepG2 were purchased from Shanghai Cell Bank (Shanghai, China) and cultured in Dulbecco's modified Eagle's medium (Wisent, South America) with 15\% fetal bovine serum (FBS; Wisent, South America). Cells were incubated in normoxic $\left(21 \% \mathrm{O}_{2}, 5 \% \mathrm{CO}_{2}\right)$ or hypoxic $\left(1 \% \mathrm{O}_{2}, 5 \% \mathrm{CO}_{2}, 94 \% \mathrm{~N}_{2}\right)$ conditions with a humidified chamber at $37^{\circ} \mathrm{C}$.

\section{HIF-2 $\alpha$ negative control and inhibitor, transient and stable transfection}

To silence the expression of HIF- $\alpha$, for stable transfection the plasmids pGPU6/GFP/Neo-HIF- $2 \alpha-$ homo-1250 and pGPU6/GFP/Neo-shNC were designed and synthesized by GenePharma (Shanghai, China; Table 1). For transient transfection, HIF-2 $\alpha$-silencing small interfering RNA (siRNA; EPAS1-homo-2778) and negative control siRNA (siNC) were also obtained from GenePharma (Shanghai, China; Table 2).

For gene transfection, the cells were cultured in 6-well plates to $50 \%$ confluence. The plasmids or siRNAs were transfected into cells using Lipofectamine 2000 in accordance with the manufacturer's instructions (Invitrogen, USA). Cells were transfected for $6 \mathrm{~h}$ in medium without FBS. After changing to normal culture medium and culturing for $48 \mathrm{~h}$, siRNA and siNC cells in transient transfection were prepared for further experiments. For stable transfection, $1 \mathrm{mg} / \mathrm{mL}$ G418 was incubated with cells for $14 \mathrm{~d}$ to obtain stable transfected cell lines (shRNA and shNC cells).

\section{Real-time quantitative PCR}

Total RNA from cells was extracted using Trizol reagent (Invitrogen, Carlsbad, CA, USA), and cDNA was synthesized using the PrimeScript RT Kit (Takara) in accordance with the manufacturer's instructions. Concentrations were measured using a NanoDrop spectrophotometer (ND-1000V3.5.2 software, USA). RT- 
Table 1. Sequences of HIF-2 $\alpha$ inhibitor and negative control for stable transfection

\begin{tabular}{|c|c|c|}
\hline & \multicolumn{2}{|c|}{ Primer sequences $\left(5^{\prime} \rightarrow 3^{\prime}\right)$} \\
\hline \multirow{6}{*}{$\begin{array}{l}\text { pGPU6/GFP/Neo- } \\
\text { HIF-2 } \alpha \text {-homo-1250 }\end{array}$} & Sense & CACCGCCACAGCATGGACATG \\
\hline & & AAGTTTCAAGAGAACTTCATG \\
\hline & & TCCATGCTGTGGCTTTTTTG \\
\hline & Antisense & GATCCAAAAAAGCCACAGCAT \\
\hline & & GGACATGAAGTTCTCTTGAAA \\
\hline & & CTTCATGTCCATGCTGTGGC \\
\hline \multirow[t]{6}{*}{ pGPU6/GFP/Neo-shNC } & Sense & CACCGTTCTCCGAACGTGTCAC \\
\hline & & GTCAAGAGATTACGTGACACG \\
\hline & & TTCGGAGAATTTTTTG \\
\hline & Antisense & GATCCAAAAAATTCTCCGAACG \\
\hline & & TGTCACGTAATCTCTTGACGTG \\
\hline & & ACACGTTCGGAGAAC \\
\hline
\end{tabular}

Table 2. Sequences of HIF-2 $\alpha$ inhibitor and negative control for transient transfection

\begin{tabular}{ccc}
\hline & \multicolumn{2}{c}{ Primer sequences $\left(5^{\prime} \rightarrow 3^{\prime}\right)$} \\
\hline EPAS1-homo-2778 & Sense & GCGCAAAUGUACCCAAUGAT \\
& Antisense & UCAUUGGGUACAUUUGCGCTT \\
siNC & Sense & UUCUCCGAACGUGUCACGUTT \\
& Antisense & ACGUGACACGUUCGGAGAATT \\
\hline
\end{tabular}

Table 3. Sequences of target genes

\begin{tabular}{|c|c|c|}
\hline \multirow{3}{*}{$H I F-2 \alpha$} & \multicolumn{2}{|c|}{ Primer sequences $\left(5^{\prime} \rightarrow 3^{\prime}\right)$} \\
\hline & $\mathrm{F}$ & ATGAAGAGCAAGCCTTCCAG \\
\hline & $\mathrm{R}$ & TGGGGTTTTGGGTGAACTTA \\
\hline \multirow[t]{2}{*}{ ADRP } & $\mathrm{F}$ & CAGACCATTTCTCAGCTCCA \\
\hline & $\mathrm{R}$ & GGCAATTGCAAGAGTACGTG \\
\hline \multirow[t]{2}{*}{ 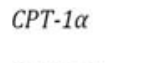 } & $\mathrm{F}$ & ATGAGTCGTGCCACCAAGAT \\
\hline & $\mathrm{R}$ & AAGAGGCCTCACCGACTGTA \\
\hline \multirow[t]{2}{*}{ SREBP-2 } & $\mathrm{F}$ & CTACGGTGCAGACAGTTGCT \\
\hline & $\mathrm{R}$ & CCACCAGGGTTGGTACTTGA \\
\hline \multirow[t]{2}{*}{$L D L R$} & $\mathrm{~F}$ & TCTGCAACATGGCTAGAGACT \\
\hline & $\mathrm{R}$ & TCCAAGCATTCGTTGGTCCC \\
\hline \multirow[t]{2}{*}{$H M G C R$} & $\mathrm{~F}$ & TGATTGACCTTTCCAGAGCAAG \\
\hline & $\mathrm{R}$ & CTAAAATTGCCATTCCACGAGC \\
\hline \multirow[t]{2}{*}{ CYP7A1 } & $\mathrm{F}$ & GAGAAGGCAAACGGGTGAAC \\
\hline & $\mathrm{R}$ & GGATTGGCACCAAATTGCAGA \\
\hline \multirow[t]{2}{*}{$A B C A 1$} & $\mathrm{~F}$ & TAATGCCAACAACCCCTGTT \\
\hline & $\mathrm{R}$ & GGAACCCAGAGAAGGTTTCA \\
\hline \multirow[t]{2}{*}{ ABCG5 } & $\mathrm{F}$ & GGTCTCCTTTACCAGTTTGTGG \\
\hline & $\mathrm{R}$ & ATATCCAAATCGGGCAACCT \\
\hline \multirow[t]{2}{*}{ ABCG8 } & $\mathrm{F}$ & AGAGACCTTGGCCTTCATTG \\
\hline & $\mathrm{R}$ & GAAGCTGTCGAGCCCAGA \\
\hline \multirow[t]{2}{*}{ GAPDH } & $\mathrm{F}$ & CAGCCTCAAGATCATCAGCA \\
\hline & $\mathrm{R}$ & TGTGGTCATGAGTCCTTCCA \\
\hline \multirow[t]{2}{*}{ Hif-2a (Mus) } & $\mathrm{F}$ & GAGGAAGGAGAAATCCCGTGA \\
\hline & $\mathrm{R}$ & TATGTGTCCGAAGGAAGCTGA \\
\hline \multirow[t]{2}{*}{ Gapdh (Mus) } & $\mathrm{F}$ & CCTGGAGAAACCTGCCAAGTA \\
\hline & $\mathrm{R}$ & TGGAAGAGTGGGAGTTGCTGT \\
\hline
\end{tabular}

qPCR was performed with FastStart Universal SYBR Green Master (Rox) (Roche, USA) with an ABI StepOne machine (Applied Biosystems, Life Technologies, CA, USA). Briefly, qPCR cycling was performed as follows: initial denaturation at $95^{\circ} \mathrm{C}$ for $10 \mathrm{~min} ; 40$ cycles of denaturation at $95^{\circ} \mathrm{C}$ for $10 \mathrm{~s}$; annealing for $60 \mathrm{~s}$ at 60 ${ }^{\circ} \mathrm{C}$; and a melting curve profile set at $95{ }^{\circ} \mathrm{C}$ for $15 \mathrm{~s}, 60{ }^{\circ} \mathrm{C}$ for $15 \mathrm{~s}$, and $95^{\circ} \mathrm{C}$ for $15 \mathrm{~s}$. Transcript expression levels were normalized using glyceraldehyde 3-phosphate dehydrogenase (GAPDH) levels as an endogenous control. Primers for qPCR were synthesized by Invitrogen (Shanghai, China; Table 3).

\section{Western blot analysis}

Proteins were prepared by homogenizing cells in RIPA buffer (Beyotime, China) containing a protease inhibitor cocktail mix from cOmplete ULTRA Tablets (Roche, Germany) on ice. The protein concentration was determined using a bicinchoninic acid protein assay kit (Keygen, Nanjing, China). Proteins were resolved via SDS-PAGE, transferred to polyvinylidene fluoride membranes (Millipore, Temecula, CA, USA), blocked with milk for $2 \mathrm{~h}$, probed with primary antibodies at $4{ }^{\circ} \mathrm{C}$ overnight, and incubated with secondary antibodies for $2 \mathrm{~h}$ at room temperature. The primary antibodies were: HIF- $2 \alpha$ (Abcam, Cambridge, MA, USA), HIF- $1 \alpha$ (human; Cell Signaling, USA), HIF-1 $\alpha$ (mus; Santa Cruz, USA), and SREBP-1 ( Santa Cruz, USA), each used at a dilution of 1:200; FAS (Cell Signaling, USA) was diluted at 1:1000; $\beta$-actin and GAPDH from BioWorld (Irving, TX, USA) were diluted at 1:1000. Secondary antibodies were obtained from ZhongShan JinQiao (China). Protein levels were normalized to $\beta$-actin or GAPDH. Electrochemiluminescence was analyzed with a Chemilmager 5500 imaging system (Alpha Innotech, San Leandro, CA, USA).

\section{Analysis of lipid accumulation via Nile red staining}

HepG2 cells were plated in 6-well plates. Cells were fixed with $3.7 \%$ formaldehyde in phosphatebuffered saline (PBS) for $30 \mathrm{~min}$ and then rinsed twice with PBS. The cells were stained with Nile red (1 $\mu \mathrm{g} /$ $\mathrm{mL}$ ) in 60\% 2-propanol for 5 min and washed three times with PBS. Images were taken with an inverted fluorescence microscope (Olympus, Tokyo, Japan) equipped with an image recorder under a 10× lens.

\section{Analysis of free cholesterol accumulation via Filipin staining}

HepG2 cells at a concentration of $1 \times 10^{4} / \mathrm{mL}$ were cultured on $22 \mathrm{~mm} \times 22 \mathrm{~mm}$ coverslips in 6 -well plates overnight. According to group, the corresponding treatment was given. Cells were washed with PBS and fixed with $3.7 \%$ formaldehyde in PBS for $30 \mathrm{~min}$ at $4{ }^{\circ} \mathrm{C}$. They were subsequently treated with $0.1 \%$ 


\section{Cellular Physiology and Biochemistry}

Cell Physiol Biochem 2014;34:1427-1441

\begin{tabular}{l|l}
\hline DOI: $10.1159 / 000366348$ & (C) 2014 S. Karger AG, Basel
\end{tabular}

www.karger.com/cpb

Cao et al.: HIF-2 $\alpha$ Regulates Lipid Metabolism

Triton for $3 \mathrm{~min}$, and washed three times with PBS. Cells were stained with $50 \mu \mathrm{g} / \mathrm{mL}$ Filipin III fluorescent dye at $37{ }^{\circ} \mathrm{C}$ for $30 \mathrm{~min}$ and washed with PBS three times. Images were obtained with a fluorescent microscope (Olympus) at $10 \times$ lens.

\section{Measurement of intracellular free cholesterol and triglyceride levels}

HepG2 cells were collected and homogenized in RIPA buffer. Intracellular triglyceride and free cholesterol were measured by using triglyceride and free cholesterol assay kits (Biovision, USA), in accordance with the kit manuals. Triglyceride and cholesterol levels were normalized to total protein concentrations.

\section{Measurements of HADH activity}

HADH activity was measured as described previously [29, 30]. Briefly, HepG2 cell pellets were homogenized in 1:10 wt/vol homogenization buffer (50 mM Tris- $\mathrm{HCl}, 1 \mathrm{mM}$ EDTA, 10\% glycerol [wt/vol], $0.1 \%$ Triton-100). After homogenization, the cell lysates were centrifuged at $8000 \mathrm{rpm}$ for $30 \mathrm{~min}$ at $4{ }^{\circ} \mathrm{C}$. In each well of a 96-well UV plate, $260 \mu \mathrm{L}$ imidazole (50 mM, pH 7.4), $20 \mu \mathrm{L}$ reduced nicotinamide adenine dinucleotide $\left(0.15 \mathrm{mM}, \varepsilon=6.22 \mathrm{~mol} \cdot \mathrm{mL}^{-1} \cdot \mathrm{cm}^{-1}\right)$, and $10 \mu \mathrm{L}$ cell lysate were added. The absorbance was detected at $30^{\circ} \mathrm{C}$ with a SpectraMax 190 spectrophotometer (Molecular Devices), at $340 \mathrm{nM}$ for 5 min with 30 -s intervals both before (baseline) and after adding $10 \mu \mathrm{L}$ of $3 \mathrm{mM}$ acetoacetyl CoA. HADH activity was normalized to total protein concentrations.

\section{Measurements of Cholesterol Efflux}

Cholesterol efflux was measured as described previously [31]. Briefly, HepG2 cells were cultured in DMEM media containing 15\% FBS, trace labeled with $1 \mu \mathrm{Ci} / \mathrm{ml}{ }^{3} \mathrm{H}$-cholesterol (Perkin-Elmer, USA) overnight. Before treatment, cells were washed with PBS and equilibrated in media for $2 \mathrm{~h}$. Cells were then incubated under normoxia or hypoxia conditions for $24 \mathrm{~h}$, in serum free DMEM containing $10 \mu \mathrm{g} / \mathrm{ml}$ apoA-I and $2 \mathrm{mg} / \mathrm{ml}$ fatty acid-free BSA for $24 \mathrm{~h}$. Supernatants were collected, centrifuged to remove cell debris, and radioactivity was quantified by scintillation counting (Microbeta2, Perkin Elmer). Cells were washed with PBS and lysed with $0.1 \mathrm{M} \mathrm{NaOH}$, and cell lysates were analyzed by scintillation counting. Cholesterol efflux was calculated by cpm in media/(cpm in media+cpm in cellular lipid) and expressed in percent.

\section{Statistical analysis}

The equation $2^{-\Delta \Delta \mathrm{CT}}$ was applied to calculate the fold changes of gene expression. Data are presented as the mean \pm standard deviation for at least three separate experiments. Statistical analysis was performed using the paired 2-tailed Student's $t$ test. A $P$-value of $<0.05$ was considered statistically significant.

\section{Results}

HIF-2 $\alpha$ expression in HepG2 cells in vitro and in C57BL/6 mice in vivo

To assess the role of HIF- $2 \alpha$ in lipid metabolism, we first determined the HIF- $2 \alpha$ mRNA and protein levels in HepG2 cells under normoxia and hypoxia (Fig. 1A, 1C). HIF-2 $\alpha$ protein expression increased in hypoxia over time, in vitro reaching a maximum at 24 h of hypoxia. However, there was no change in $H I F-2 \alpha$ mRNA levels.

To confirm our in vitro data, we created mouse liver models of ischemic-reperfusion. RNAs and protein was extracted from hepatic tissues as described in Methods. RT-qPCR and western blot analysis both revealed a slight but statistically significant increase in HIF- $2 \alpha$ expression in IR mice compared to controls (Fig. 1B, 1D). We also determined quantities of HIF-1 $\alpha$ protein both in vitro and in vivo and obtained similar results (Fig. 1E, 1F).

\section{Establishment of HIF-2 $\alpha$-silenced HepG2 cell lines}

In the present study, we established stable HIF-2 $\alpha$-silenced (shRNA) and negative control (shNC) cell lines by selecting transfected cells with G418. The transfection efficiency was $35 \%$ to $40 \%$. The knockdown efficiency was confirmed by western blot analysis (Fig. 2A). 


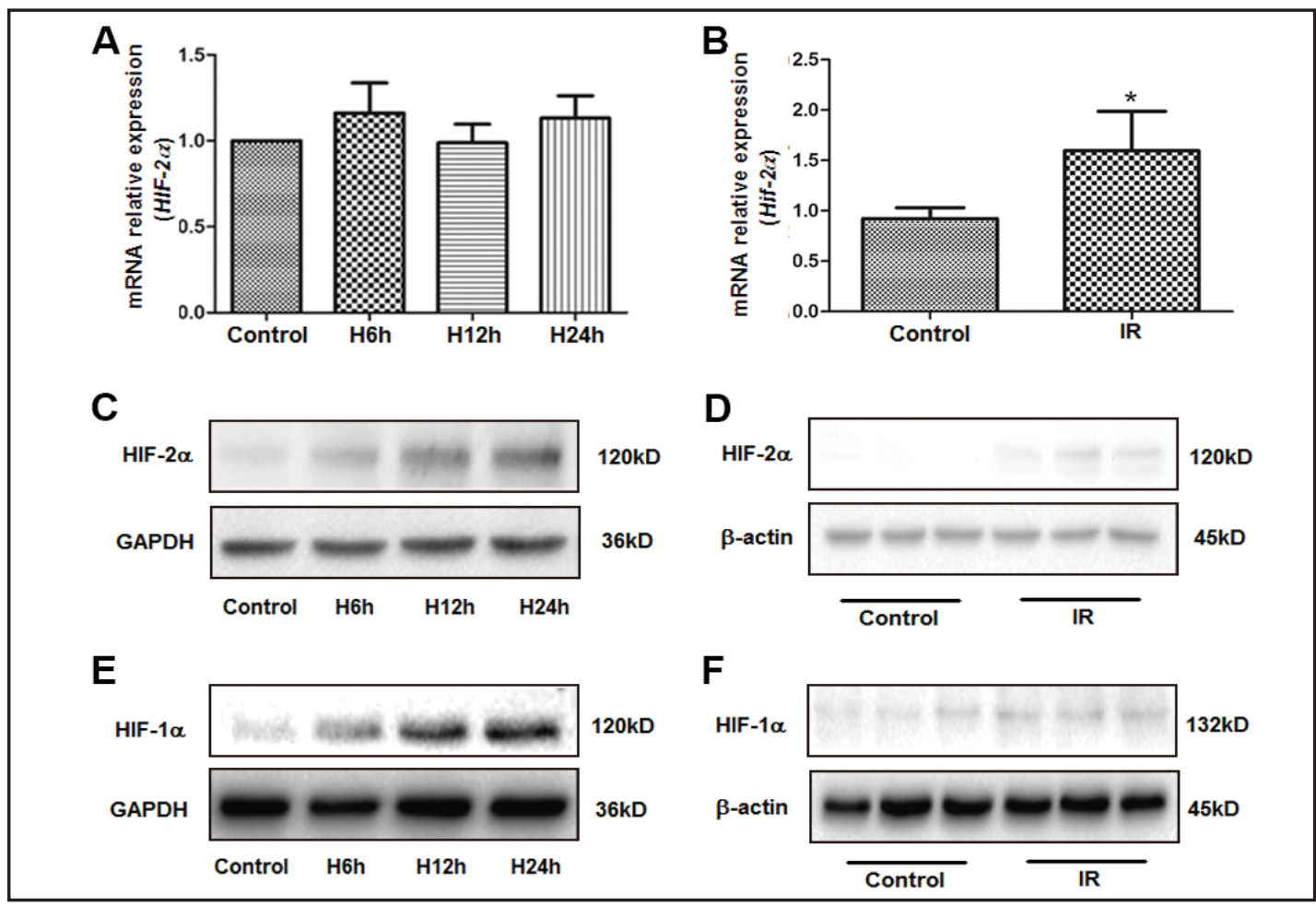

Fig. 1. HIF-2 $\alpha$ and HIF-1 $\alpha$ expression in HepG2 cells in vitro and in C57BL/6 mice in vivo. (A, C, E) HepG2 cells were cultured under hypoxic $\left(1 \% \mathrm{O}_{2}\right)$ conditions for 6,12 and $24 \mathrm{~h}$ (group $\mathrm{H}$ ). Total cell lysates were obtained to determine intracellular HIF- $\alpha$ and HIF- $1 \alpha$ expressions by RT-qPCR and western blot analysis $(\mathrm{n}=3)$. (B, D, F) C57BL/6 mice were treated with ischemia-reperfusion for 6 h (group IR). Liver HIF- $2 \alpha$ and HIF- $1 \alpha$ expressions were detected via RT-qPCR and western blot analysis $(n=3)$. Each immunoblot is representative of three separate experiments. GAPDH and $\beta$-actin were used as internal controls. ${ }^{*} P<0.05$, IR group compared with untreated control groups.

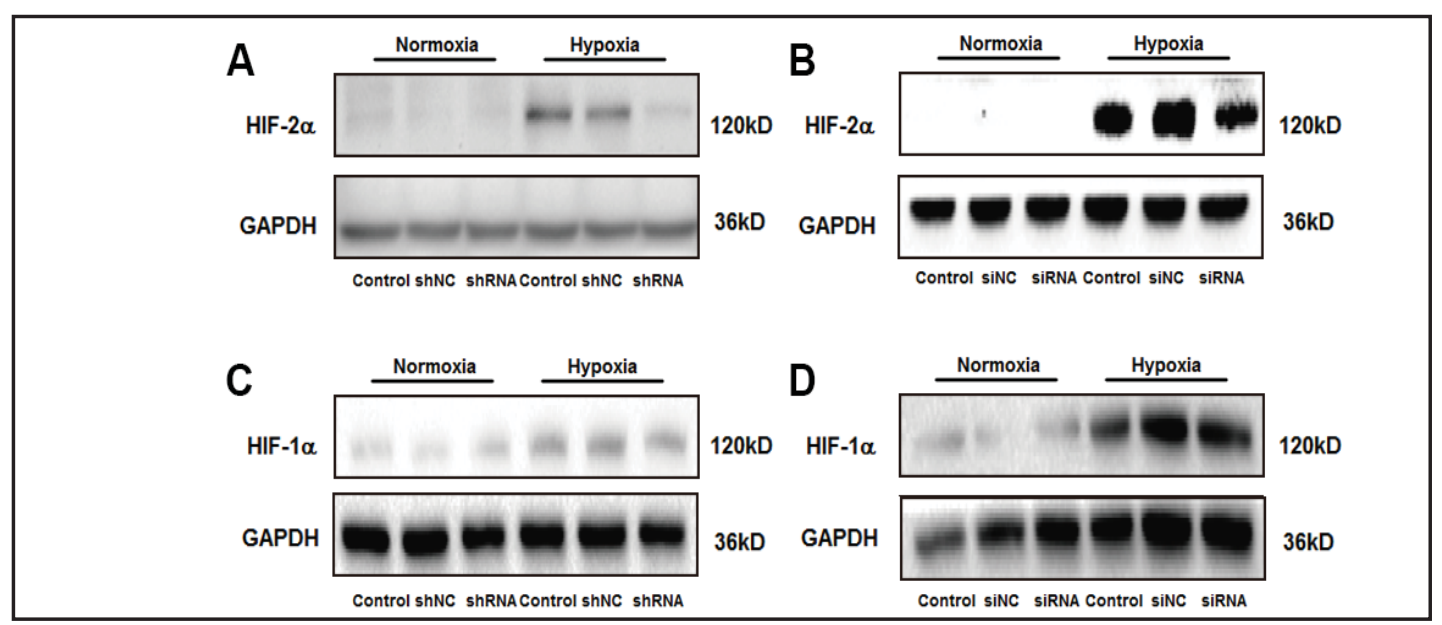

Fig. 2. Establishment of HIF-2 $\alpha$-silenced HepG2 cell lines. Cells were cultured in 6-well plates and transfected with pGPU6 plasmid DNA ( $4 \mu \mathrm{g}$ ) or HIF-2 $\alpha$ siRNA ( $100 \mathrm{pM}$ ) by Lipofectamine 2000 . After $6 \mathrm{~h}$ incubation, the culture media were changed to normal media and kept for $48 \mathrm{~h}$ until treated. For the stable transfection, cells were treated with $1 \mathrm{mg} / \mathrm{mL}$ G418 for $14 \mathrm{~d}$. Cells were cultured under normoxic $\left(21 \% \mathrm{O}_{2}\right)$ or hypoxic $\left(1 \% \mathrm{O}_{2}\right)$ conditions for $24 \mathrm{~h}$, and intracellular HIF- $2 \alpha$ and HIF-1 $\alpha$ protein expressions were detected by western blot analysis in total cell lysates. (A, C) HIF expressions of stable transfection (B, D) HIF expressions of transient transfection. Each immunoblot is representative of three separate experiments. GAPDH was used as an internal control. 


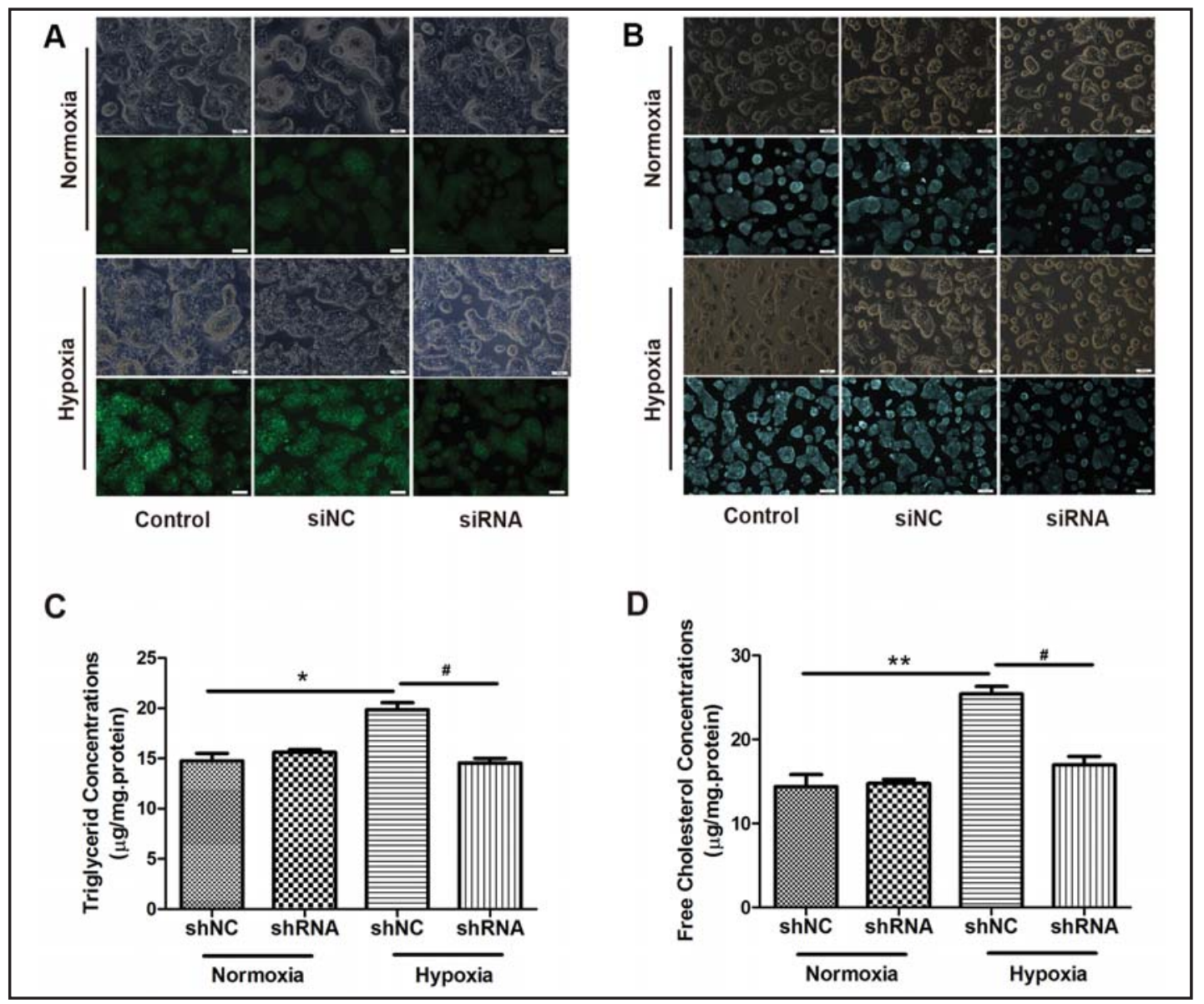

Fig. 3. Effect of hypoxia and HIF-2 $\alpha$ on lipid accumulation. HepG2 cells were plated in 6 -well plates and transfected with HIF-2 $\alpha$ siRNA (100 pM) by Lipofectamine 2000 for $6 \mathrm{~h}$. After $48 \mathrm{~h}$ incubation, cells were cultured under normoxic $\left(21 \% \mathrm{O}_{2}\right)$ or hypoxic $\left(1 \% \mathrm{O}_{2}\right)$ conditions for $24 \mathrm{~h}$, then fixed with $3.7 \%$ formaldehyde for $30 \mathrm{~min}$. Cells were stained by Nile red $(1 \mu \mathrm{g} / \mathrm{mL})$ for $5 \mathrm{~min}$ or Filipin III $(50 \mu \mathrm{g} / \mathrm{mL})$ for $30 \mathrm{~min}$ as described in Materials and Methods, with images obtained by fluorescence microscopy. (A) Nile red staining for lipid accumulation, detected by FITC filter (10×). (B) Filipin staining for free cholesterol accumulation, detected by DAPI filter (10x). Each image is representative of three separate experiments. The scale bar is $100 \mu \mathrm{m}$. (C, D) The shNC and HIF-2 $\alpha$-silenced HepG2 cells were cultured under normoxic or hypoxic conditions for $24 \mathrm{~h}$. The intracellular triglyceride and free cholesterol levels were determined using Biovison kits as described under Materials and Methods. ${ }^{*} P<0.05 ;{ }^{* *} P<0.01$, shNC cell hypoxia group compared with normoxia group. ${ }^{\#} P<0.05$, shRNA cells compared with shNC cells under hypoxia.

Similarly, the efficiency of knockdown in transient transfection was also confirmed by western blot (Fig. 2B). Western blot analyses showed that cells in which RNA interference (RNAi) had been used had lower levels of HIF- $2 \alpha$ protein under hypoxic conditions. However, levels in shNC and siNC cells were comparable to the corresponding controls. As expected, minor efficiency of RNA interference was demonstrated under normoxic conditions.

We detected HIF-1 $\alpha$ expression in HepG2 cells to verify the specificity of designed siRNA and shRNA, which was not reversed by HIF- $2 \alpha$ shRNA or siRNA (Fig. 2C, 2D). These results indicated that the siRNA/shRNA used in our study specifically targeted HIF- $2 \alpha$ mRNA, without an effect on the expression of HIF-1 $\alpha$.

Lipid accumulation measured by staining and quantification

To investigate lipid accumulation in HepG2 cells, we used Nile red staining. Nile red fluorescent dye binds to a wide variety of lipids including triacylglycerol and most fatty acids [32]. Under 


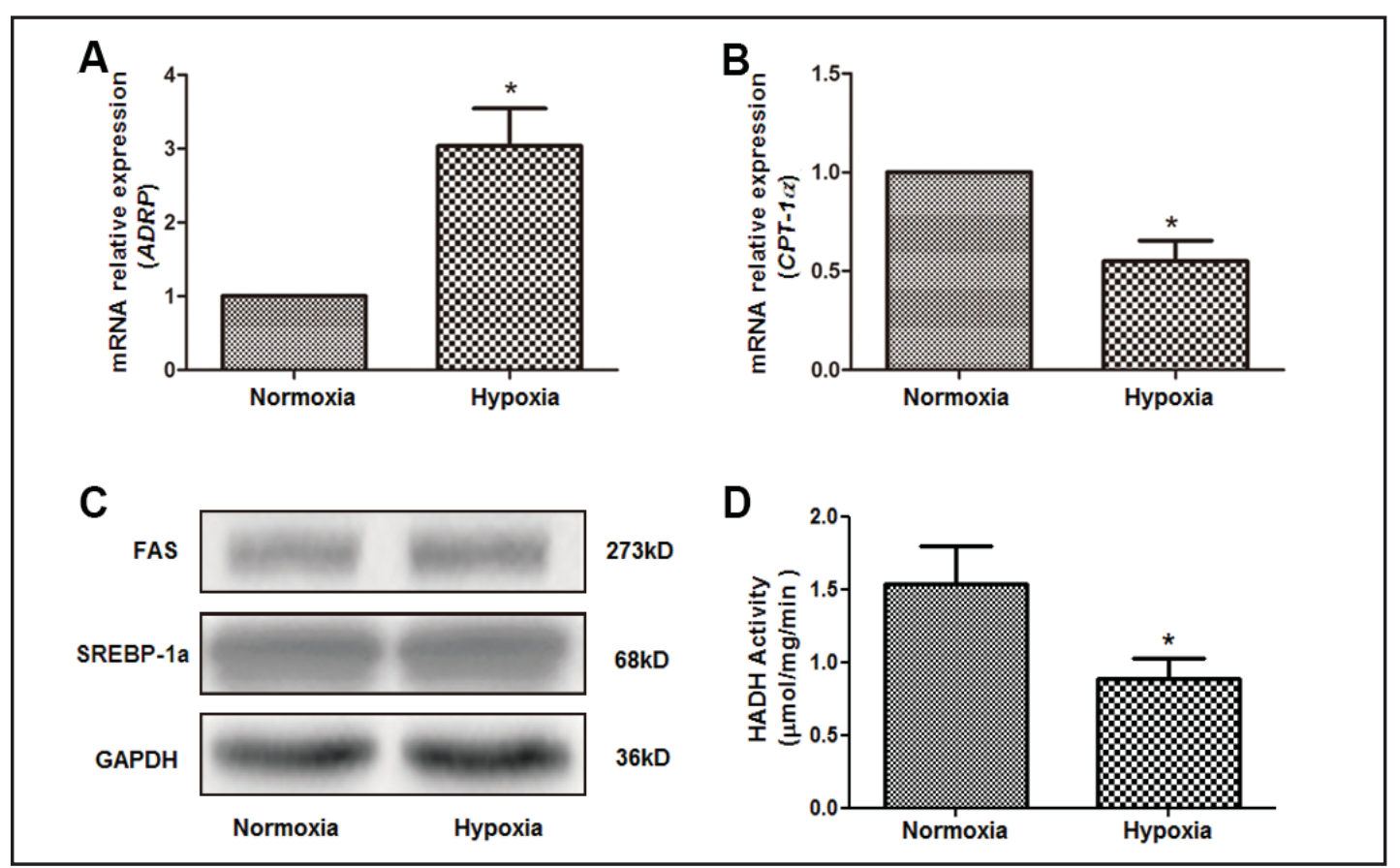

Fig. 4. Effect of hypoxia on key genes involved in fatty acid metabolism and HADH enzymatic activity. The shNC HepG2 cells were cultured under normoxic $\left(21 \% \mathrm{O}_{2}\right)$ and hypoxic $\left(1 \% \mathrm{O}_{2}\right)$ conditions for $24 \mathrm{~h}$, with total cell lysates and RNA obtained. Expressions of key genes relevant to fatty acid metabolism were determined by RT-qPCR and western blot (n=3). (A) ADRP mRNA; (B) CPT-1 $\alpha$ mRNA; (C) FAS and SREBP-1a protein, each immunoblot is representative of three separate experiments. GAPDH was used as an internal control. (D) HADH enzymatic activities examined as described in Materials and Methods $(\mathrm{n}=3) .{ }^{*} P<0.05$, hypoxia group compared with normoxia group.

normoxic conditions, the fluorescence levels of the three groups were not different (Fig. 3A). Twenty-four hours in a hypoxic environment induced marked lipid accumulation in HepG2 cells relative to the control cells that were cultured in normoxic conditions. Comparing siRNA and control cells under hypoxic environments, the results suggested that the accumulation effect was partly inhibited by silencing of HIF- $2 \alpha$, judging from the decreased fluorescence intensity. No significant differences were observed between siNC and the control cells.

We also detected free cholesterol accumulation by means of filipin staining (Fig. 3B). The results were similar to those obtained by Nile red staining. Compared to the control group, blue fluorescence obviously increased under 24-h of hypoxia, evidence of increased cholesterol accumulation. However, under hypoxic conditions the amount of fluorescence increased less in siRNA cells than in the control group, and the degree of fluorescence of siNC cells and that of the control group were very similar. These results suggest that cholesterol accumulation induced by hypoxia can be partly reversed by inhibition of HIF- $2 \alpha$.

Similar results were obtained in the quantitative measurements of lipid levels in HepG2 cells (Fig. 3C, 3D). The increased triglyceride and free cholesterol levels under hypoxic conditions were significantly prevented by silence of HIF- $2 \alpha$ expression, compared with the shNC control group.

\section{Hypoxia regulated fatty acid metabolism in HepG2 cells}

Expression of ADRP mRNA increased 3.3-fold after $24 \mathrm{~h}$ of hypoxia, while CPT-1 $\alpha$ mRNA expression was reduced by $45.1 \%(P<0.05$, both; Fig. 4A, 4B). SREBP-1a and FAS protein levels appeared to be unaffected by hypoxic conditions (Fig. 4C). HADH enzymatic activity, a measure of $\beta$-oxidation, was found to be remarkably inhibited by hypoxic conditions (Fig. 4D). 

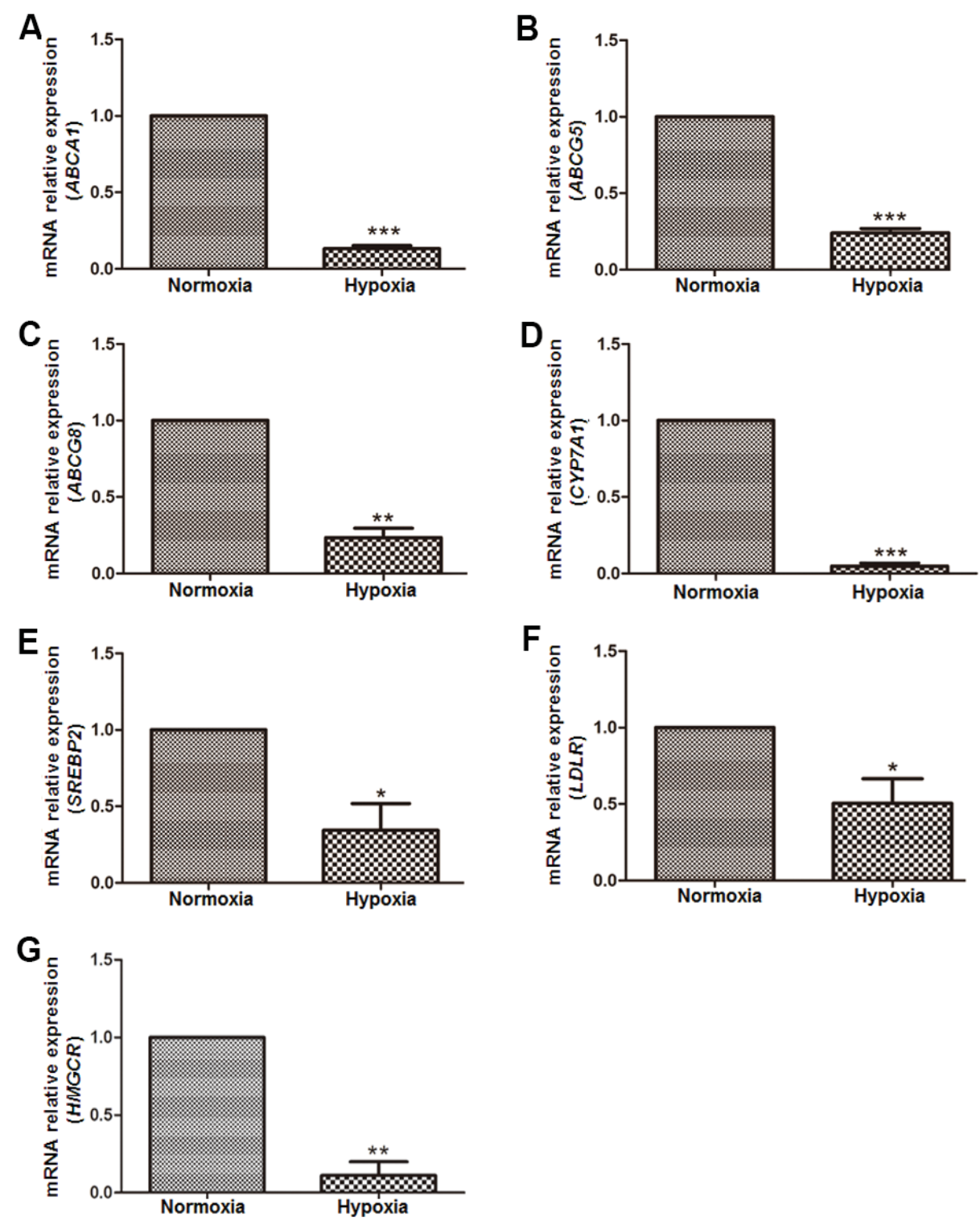

Fig. 5. Effect of hypoxia on key genes involved in cholesterol metabolism. The shNC HepG2 cells were cultured under normoxic $\left(21 \% \mathrm{O}_{2}\right)$ and hypoxic $\left(1 \% \mathrm{O}_{2}\right)$ conditions for $24 \mathrm{~h}$. The mRNA expressions of key genes relevant to cholesterol metabolism were determined by RT-qPCR analysis (n = 3). (A) ABCA1; (B) ABCG5; (C) ABCG8; (D) CYP7A1; (E) SREBP-2; (F) LDLR; (G) HMGCR. GAPDH was used as an internal control. *P< 0.05; ${ }^{* *} P<0.01 ;{ }^{* * *} P<0.001$, hypoxia group compared with normoxia group.

\section{Hypoxia regulated cholesterol metabolism in HepG2 cells}

In the case of cholesterol accumulation, genes involved in catabolism (ABCA1, ABCG5, $A B C G 8, C Y P 7 A 1$ ) all low expressed under hypoxia for $24 \mathrm{~h}$, which dropped to $13.2 \%, 24.0 \%$, $23.4 \%, 4.8 \%$, respectively (Fig. 5A-D). Unexpectedly, the mRNA expression of genes involved in anabolism (SREBP-2, LDLR, and HMGCR) also were reduced $65.7 \%, 49.6 \%$ and $89.0 \%$ under hypoxic conditions (Fig. 5E, 5F, 5G).

HIF-2 $\alpha$ regulated fatty acid metabolism in HepG2 cells under hypoxia

To explore the cellular mechanism involved in fatty acid regulation by HIF- $2 \alpha$, we examined via RT-qPCR in shRNA cells the key genes responsible for lipid uptake and 


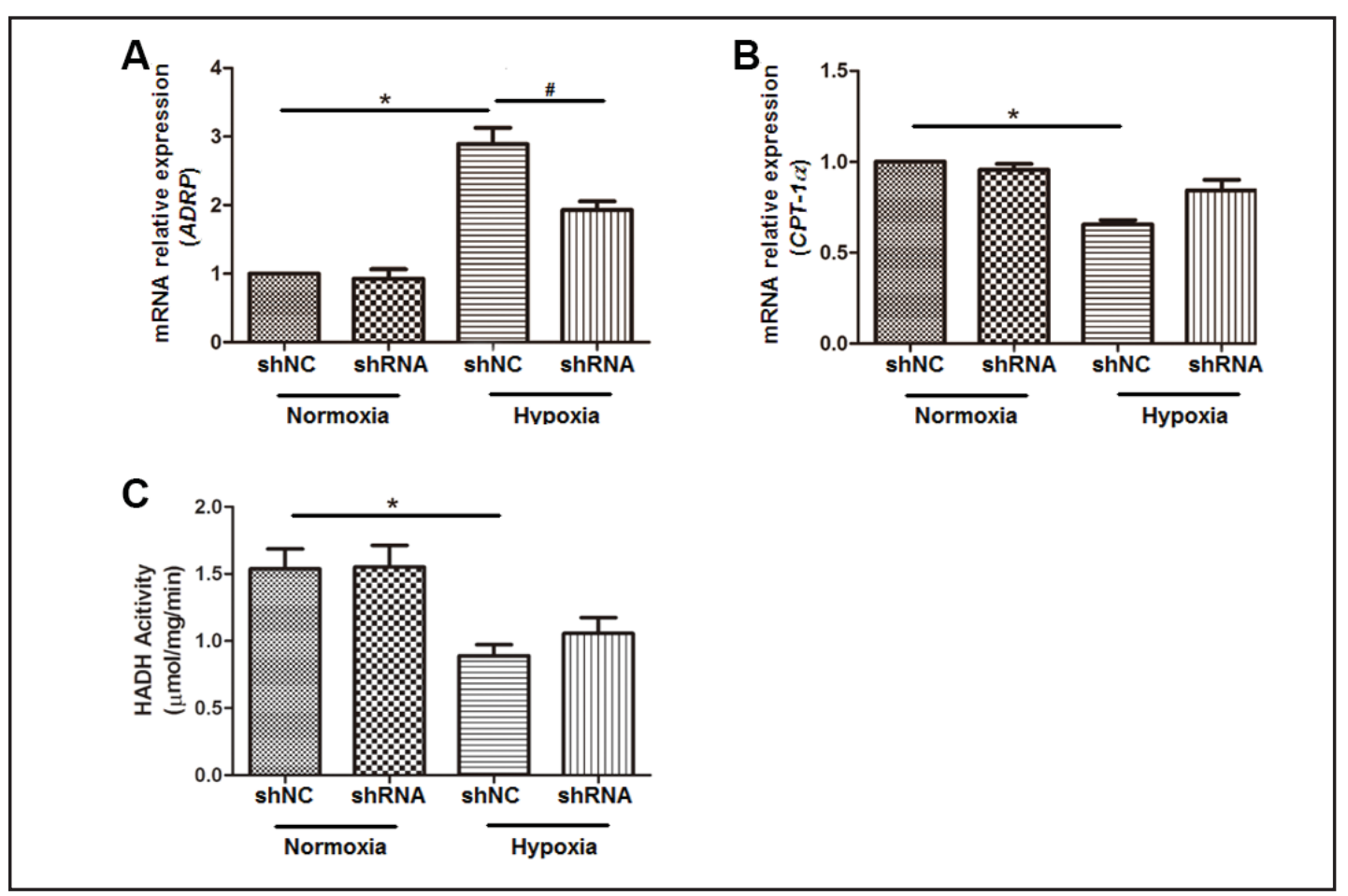

Fig. 6. Effect of HIF-2 $\alpha$ on key genes involved in fatty acid metabolism and HADH enzymatic activity. The shNC and HIF- $2 \alpha$-silenced HepG2 cells were cultured under normoxic $\left(21 \% \mathrm{O}_{2}\right)$ or hypoxic $\left(1 \% \mathrm{O}_{2}\right)$ conditions for $24 \mathrm{~h}$. The mRNA expressions of key genes relevant to fatty acid metabolism were determined by RT-qPCR (n = 3). (A) ADRP; (B) CPT-1 $\alpha$. GAPDH was used as an internal control. (C) HADH enzymatic activities examined as described in Materials and Methods $(\mathrm{n}=3) .{ }^{*} P<0.05 \mathrm{shNC}$ cells hypoxia group compared with normoxia group. ${ }^{\#} P<0.05$, shRNA cells compared with shNC cells under hypoxia.

$\beta$-oxidation. Compared to the shNC group, ADRP mRNA expression was reduced by $33 \%$ in the shRNA group under hypoxic conditions (Fig. 6A). There was no difference in CPT-1 $\alpha$ mRNA levels between the two groups under hypoxic conditions, nor in HADH enzymatic activity (Fig. 6B, 6C).

\section{HIF-2 $\alpha$ regulated cholesterol excretion in HepG2 cells under hypoxic conditions}

To further investigate the possible pathway controlled by HIF- $2 \alpha$ in cholesterol metabolism, we also evaluated by RT-qPCR the expression of key genes involved in cholesterol uptake, de novo synthesis, degradation, and reverse cholesterol transportation. Our data indicated that $A B C A 1 \mathrm{mRNA}$ had a slight but significant increase when HIF-2 $\alpha$ was silenced under hypoxia $(P<0.05 ;$ Fig. 7A). The cholesterol efflux relevant to hypoxia was also reversed obviously (Fig. $7 \mathrm{H}$ ). However, between the shRNA and corresponding shNC group there were no significant differences in the mRNA expression of the other genes of interest (SREBP-2, HMGCR, LDLR, CYP7A1, all ABCG5/8; Fig. 7B-G).

\section{Discussion}

Dysregulation of lipid metabolism is increasingly recognized as a risk factor for many metabolic diseases, including nonalcoholic fatty liver disease and cardiovascular disease. Currently it is undecided whether obstructive sleep apnea syndrome affects serum lipids [33-37], but studies suggest that hypoxia may influence lipid metabolism. HIFs are important 


\section{Cellular Physiology Cell Physiol Biochem 2014;34:1427-1441

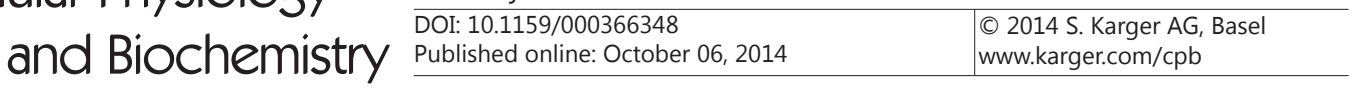

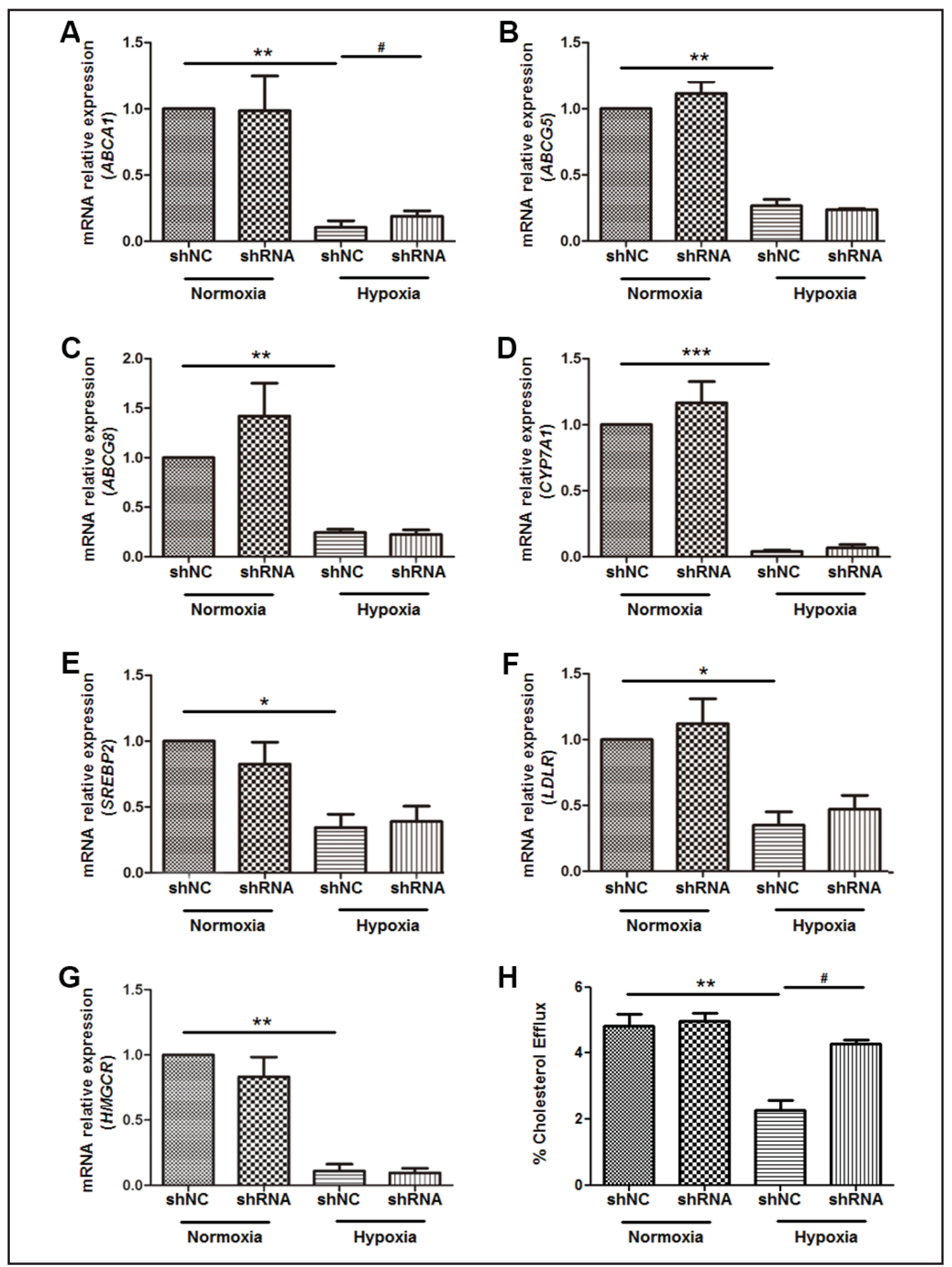

Fig. 7. Effect of HIF- $2 \alpha$ on cholesterol metabolism and efflux. The shNC and HIF- $2 \alpha$-silenced HepG 2 cells were cultured in normoxic $\left(21 \% \mathrm{O}_{2}\right)$ or hypoxic $\left(1 \% \mathrm{O}_{2}\right)$ conditions for $24 \mathrm{~h}$. The mRNA expression of key genes relevant to cholesterol metabolism were determined by RT-qPCR analysis (n = 3). (A) ABCA1; (B) ABCG5; (C) ABCG8; (D) CYP7A1; (E) SREBP-2; (F) LDLR; (G) HMGCR. GAPDH was used as an internal control. $(\mathrm{H})$ Cell cholesterol efflux were determined as described in Materials and Methods $(\mathrm{n}=3)$. Percentage was calculated by cpm in media/(cpm in media+cpm in cellular lipid) . ${ }^{*} P<0.05$; ${ }^{* *} P<0.01$; ${ }^{* * *} P<0.001$, shNC cell hypoxia group compared with normoxia group. ${ }^{\#} P<0.05$, shRNA cells compared with shNC cells under hypoxia. 


\section{Cellular Physiology and Biochemistry}

Cell Physiol Biochem 2014;34:1427-1441

DOI: 10.1159/000366348

Published onIIne: October 06, 2014

C) 2014 S. Karger AG, Basel

www.karger.com/cpb

Cao et al.: HIF-2 $\alpha$ Regulates Lipid Metabolism

transcription factors with crucial roles in allowing adaption to hypoxic environments in mammals. In the present study, we investigated the effect of HIF- $2 \alpha$ on lipid metabolism and the potential underlying molecular mechanisms.

We detected the expressions of HIF- $2 \alpha$ in HepG2 cells in vitro and in C57BL/6 male mice. Under hypoxic conditions, HIF-2 $\alpha$ mRNA and protein levels were remarkably higher both in vitro and in vivo, except that mRNA expressed in vitro was not affected by 24 -h hypoxic conditions. Data obtained from our animal experiments would be better supported by a larger sample than provided at this time. Two studies conducted by Wiesener et al. [38, 39 ] that support our findings also showed that hypoxia has an effect on HIF-2 $\alpha$ at the posttranscriptional level rather than the transcriptional level.

In the current study, we observed that lipid accumulation, including fatty acid and cholesterol, obviously increased under hypoxic conditions. Furthermore, we used siRNAs to specifically inhibit HIF-2 $\alpha$ production in the human hepatic carcinoma cell line, HepG2. Results from quantitative analysis and staining showed that both triglyceride and free cholesterol accumulation were augmented by HIF- $2 \alpha$ knockdown. Therefore, one possible explanation of hypoxia-induced lipid accumulation in hepatocytes is via a HIF- $2 \alpha$ transcription factor pathway, consistent with previous studies using mouse models $[26,40]$.

We also investigated the role of transcription factor induction of specific target genes with a variety of functions related to lipid metabolism and the hypoxic response. Our data suggest that the development of steatosis in HepG2 cells is a consequence of increased lipid uptake and reduced lipid $\beta$-oxidation. Hu et al. [41] already demonstrated that ADRP coordinates regulation of HIF- $1 \alpha$ and HIF- $2 \alpha$ in clear cell renal cancer cells. Also, ADRP was found necessary for lipid storage in fibroblasts and a variety of fatty liver disease models [14-16].

Unexpectedly, SREBP-1a and FAS, two key fatty acid synthesis relevant proteins induced by hypoxic conditions $[42,43]$ were not changed in our model. With further analysis, we found that HIF- $2 \alpha$ significantly upregulated the uptake of fatty acid (ADRP) expression. Finally, we found that reduced $\beta$-oxidation was not regulated by HIF- $2 \alpha$, although inhibition of HIF- $2 \alpha$ under hypoxia resulted in a slight increase in CPT-1 $\alpha$ mRNA expression. As a reflection of $\beta$-oxidation efficiency, HADH enzyme activities were significantly decreased under hypoxic conditions, which also were not affected by HIF- $2 \alpha$. Taken together, these data suggest that during hypoxia, ADRP signaling may be regulated by HIF- $2 \alpha$ to participate in fatty acid accumulation. This is similar to the conclusions of Rankin et al. [24].

With regard to cholesterol metabolism, in the present study hypoxia was associated with an obvious decline in expression levels of the key genes in HepG2 cells. The data suggest that hypoxia leads to accumulation of cholesterol via a decrease in biodegradation and reverse transportation. Interestingly, we found that expression of SREBP-2 varied with oxygen concentration, but presented a downward trend under hypoxia. $L D L R$ and HMGCR, which are downstream of SREBP-2, also showed similar trends. Our data is in disaccord with that of Li et al. [44, 45] who concluded that SREBP-2 signaling, as well as the SREBP-2 target $L D L R$, are not relevant to oxygen concentration in obese mice. With further analysis, we found that only ABCA1 mRNA was significantly elevated by the inhibition of HIF- $2 \alpha$ during hypoxic conditions. Furthermore, we validated that the hypoxia related cholesterol excretion was also regulated by HIF- $2 \alpha$. Other pathways affected by hypoxia may be through other mechanisms. One potential pathway mediated by HIF-1 $\alpha$ was suggested by Parathath et al. [46] and Manalo et al.[47]. Endoplasmic reticulum stress may also participate in regulation of lipid metabolism [48-51].

In conclusion, inhibition of HIF- $2 \alpha$ protein reversed hypoxia-induced lipid accumulation in HepG2 cells by decreasing the expression of $A D R P$, involved in fatty acid uptake, increasing $A B C A 1$ expression and relevant cholesterol excretion. These results suggest a possible mechanism for lipid metabolism dysregulation induced by acute hypoxia. These findings indicate that HIF- $2 \alpha$ signaling is relevant to oxygen-dependent lipid homeostasis in the liver, and may have implications for the therapeutic treatment of fatty liver and cardiovascular diseases. 


\section{Cellular Physiology \\ and Biochemistry}

Cell Physiol Biochem 2014;34:1427-1441

\begin{tabular}{l|l}
\hline DOI: $10.1159 / 000366348$ & (C) 2014 S. Karger AG, Basel
\end{tabular}

\begin{tabular}{l|l} 
Published onIIne: October 06, 2014 & www.karger.com/cpb
\end{tabular}

Cao et al.: HIF-2 $\alpha$ Regulates Lipid Metabolism

\section{Disclosure Statement}

All authors report no conflicts of interest.

\section{Acknowledgements}

We would like to express our gratitude to Dr. Junjie Qin and Dr. Jiajie Hou (Nanjing Medical University, China) for technical assistance with the animal study, Dr. Beth Shoshana Zha (Virginia Commonwealth University, USA) and Meijaden Company (Hongkong, China) for help with the native English editing of the manuscript. The study was supported by the National Natural Science Foundation of China (No.81100273; 81100274) and the innovation projects of Jiangsu Province Hospital (No.CX11)

\section{References}

1 Byrne CD: Hypoxia and non-alcoholic fatty liver disease. Clin Sci (Lond) 2010;118:397-400.

-2 Semenza GL: Oxygen sensing, hypoxia-inducible factors, and disease pathophysiology. Annu Rev Pathol 2014;9:47-71.

-3 Higuchi N, Kato M, Shundo Y, Tajiri H, Tanaka M, Yamashita N, Kohjima M, Kotoh K, Nakamuta M, Takayanagi R, Enjoji M: Liver X receptor in cooperation with SREBP-1c is a major lipid synthesis regulator in nonalcoholic fatty liver disease. Hepatol Res 2008;38:1122-1129.

-4 Magana MM, Koo SH, Towle HC, Osborne TF: Different sterol regulatory element-binding protein-1 isoforms utilize distinct co-regulatory factors to activate the promoter for fatty acid synthase. J Biol Chem 2000;275:4726-4733.

5 Nguyen P, Leray V, Diez M, Serisier S, Le Bloc'h J, Siliart B, Dumon H: Liver lipid metabolism. J Anim Physiol Anim Nutr (Berl) 2008;92:272-283.

6 Bengoechea-Alonso MT, Ericsson J: SREBP in signal transduction: cholesterol metabolism and beyond. Curr Opin Cell Biol 2007;19:215-222.

-7 Horton JD, Goldstein JL, Brown MS: SREBPs: activators of the complete program of cholesterol and fatty acid synthesis in the liver. J Clin Invest 2002;109:1125-1131.

8 Burg JS, Espenshade PJ: Regulation of HMG-CoA reductase in mammals and yeast. Prog Lipid Res 2011;50:403-410.

-9 Jo Y, Debose-Boyd RA: Control of cholesterol synthesis through regulated ER-associated degradation of HMG CoA reductase. Crit Rev Biochem Mol Biol 2010;45:185-198.

10 Yang SY, He XY, Schulz H: 3-Hydroxyacyl-CoA dehydrogenase and short chain 3-hydroxyacyl-CoA dehydrogenase in human health and disease. FEBS J 2005;272:4874-4883.

11 Gilardi F, Mitro N, Godio C, Scotti E, Caruso D, Crestani M, De Fabiani E: The pharmacological exploitation of cholesterol 7alpha-hydroxylase, the key enzyme in bile acid synthesis: from binding resins to chromatin remodelling to reduce plasma cholesterol. Pharmacol Ther 2007;116:449-472.

-12 Gupta S, Stravitz RT, Dent P, Hylemon PB: Down-regulation of cholesterol 7alpha-hydroxylase (CYP7A1) gene expression by bile acids in primary rat hepatocytes is mediated by the c-Jun $\mathrm{N}$-terminal kinase pathway. J Biol Chem 2001;276:15816-15822.

-13 Noshiro M, Usui E, Kawamoto T, Kubo H, Fujimoto K, Furukawa M, Honma S, Makishima M, Honma K, Kato Y: Multiple mechanisms regulate circadian expression of the gene for cholesterol 7alpha-hydroxylase (Cyp7a), a key enzyme in hepatic bile acid biosynthesis. J Biol Rhythms 2007;22:299-311.

-14 Field FJ, Watt K, Mathur SN: Origins of intestinal ABCA1-mediated HDL-cholesterol. J Lipid Res 2008;49:2605-2619.

-15 Wang N, Tall AR: Regulation and mechanisms of ATP-binding cassette transporter A1-mediated cellular cholesterol efflux. Arterioscler Thromb Vasc Biol 2003;23:1178-1184.

16 Dikkers A, Freak de Boer J, Annema W, Groen AK, Tietge UJ: Scavenger receptor BI and ABCG5/G8 differentially impact biliary sterol secretion and reverse cholesterol transport in mice. Hepatology 2013;58:293-303. 


\section{Cellular Physiology and Biochemistry}

Cell Physiol Biochem 2014;34:1427-1441

\begin{tabular}{l|l}
\hline DOI: $10.1159 / 000366348$ & (C) 2014 S. Karger AG, Basel
\end{tabular}

Cao et al.: HIF-2 $\alpha$ Regulates Lipid Metabolism

17 Kidambi S, Patel SB: Cholesterol and non-cholesterol sterol transporters: ABCG5, ABCG8 and NPC1L1: a review. Xenobiotica 2008;38:1119-1139.

18 Majmundar AJ, Wong WJ, Simon MC: Hypoxia-inducible factors and the response to hypoxic stress. Mol Cell 2010;40:294-309.

19 Patel SA, Simon MC: Biology of hypoxia-inducible factor-2alpha in development and disease. Cell Death Differ 2008;15:628-634.

-20 Tian H, McKnight SL, Russell DW: Endothelial PAS domain protein 1 (EPAS1), a transcription factor selectively expressed in endothelial cells. Genes Dev 1997;11:72-82.

-21 Narravula S, Colgan SP: Hypoxia-inducible factor 1-mediated inhibition of peroxisome proliferatoractivated receptor alpha expression during hypoxia. J Immunol 2001;166:7543-7548.

-22 Gimm T, Wiese M, Teschemacher B, Deggerich A, Schodel J, Knaup KX, Hackenbeck T, Hellerbrand C, Amann K, Wiesener MS, Honing S, Eckardt KU, Warnecke C: Hypoxia-inducible protein 2 is a novel lipid droplet protein and a specific target gene of hypoxia-inducible factor-1. FASEB J 2010;24:4443-4458.

-23 Nishiyama Y, Goda N, Kanai M, Niwa D, Osanai K, Yamamoto Y, Senoo-Matsuda N, Johnson RS, Miura S, Kabe Y, Suematsu M: HIF-1alpha induction suppresses excessive lipid accumulation in alcoholic fatty liver in mice. J Hepatol 2012;56:441-447.

24 Rankin EB, Rha J, Selak MA, Unger TL, Keith B, Liu Q, Haase VH: Hypoxia-inducible factor 2 regulates hepatic lipid metabolism. Mol Cell Biol 2009;29:4527-4538.

-25 Minamishima YA, Moslehi J, Padera RF, Bronson RT, Liao R, Kaelin WG Jr: A feedback loop involving the Phd3 prolyl hydroxylase tunes the mammalian hypoxic response in vivo. Mol Cell Biol 2009;29:5729-5741.

26 Scortegagna M, Ding K, Oktay Y, Gaur A, Thurmond F, Yan LJ, Marck BT, Matsumoto AM, Shelton JM, Richardson JA, Bennett MJ, Garcia JA: Multiple organ pathology, metabolic abnormalities and impaired homeostasis of reactive oxygen species in Epas1-/- mice. Nat Genet 2003;35:331-340.

-27 Kim WY, Safran M, Buckley MR, Ebert BL, Glickman J, Bosenberg M, Regan M, Kaelin WG Jr: Failure to prolyl hydroxylate hypoxia-inducible factor alpha phenocopies VHL inactivation in vivo. EMBO J 2006;25:46504662 .

28 Abe Y, Hines IN, Zibari G, Pavlick K, Gray L, Kitagawa Y, Grisham MB: Mouse model of liver ischemia and reperfusion injury: method for studying reactive oxygen and nitrogen metabolites in vivo. Free Radic Biol Med 2009;46:1-7.

-29 Ito M, Jaswal JS, Lam VH, Oka T, Zhang L, Beker DL, Lopaschuk GD, Rebeyka IM: High levels of fatty acids increase contractile function of neonatal rabbit hearts during reperfusion following ischemia. Am J Physiol Heart Circ Physiol 2010;298:H1426-1437.

- 30 Shrivastav S, Zhang L, Okamoto K, Lee H, Lagranha C, Abe Y, Balasubramanyam A, Lopaschuk GD, Kino T, Kopp JB: HIV-1 Vpr enhances PPARbeta/delta-mediated transcription, increases PDK4 expression, and reduces PDC activity. Mol Endocrinol 2013;27:1564-1576.

-31 Rohrl C, Eigner K, Winter K, Korbelius M, Obrowsky S, Kratky D, Kovacs WJ, Stangl H: Endoplasmic reticulum stress impairs cholesterol efflux and synthesis in hepatic cells. J Lipid Res 2014;55:94-103.

32 Greenspan P, Mayer EP, Fowler SD: Nile red: a selective fluorescent stain for intracellular lipid droplets. J Cell Biol 1985;100:965-973.

-33 Coughlin SR, Mawdsley L, Mugarza JA, Calverley PM, Wilding JP: Obstructive sleep apnoea is independently associated with an increased prevalence of metabolic syndrome. Eur Heart J 2004;25:735-741.

-34 Drager LF, Bortolotto LA, Maki-Nunes C, Trombetta IC, Alves MJ, Fraga RF, Negrao CE, Krieger EM, LorenziFilho G: The incremental role of obstructive sleep apnoea on markers of atherosclerosis in patients with metabolic syndrome. Atherosclerosis 2010;208:490-495.

-35 Roche F, Sforza E, Pichot V, Maudoux D, Garcin A, Celle S, Picard-Kossovsky M, Gaspoz JM, Barthelemy JC, Group PS: Obstructive sleep apnoea/hypopnea influences high-density lipoprotein cholesterol in the elderly. Sleep Med 2009;10:882-886.

-36 Tan KC, Chow WS, Lam JC, Lam B, Wong WK, Tam S, Ip MS: HDL dysfunction in obstructive sleep apnea. Atherosclerosis 2006;184:377-382.

-37 Tokuda F, Sando Y, Matsui H, Koike H, Yokoyama T: Serum levels of adipocytokines, adiponectin and leptin, in patients with obstructive sleep apnea syndrome. Intern Med 2008;47:1843-1849.

-38 Wiesener MS, Jurgensen JS, Rosenberger C, Scholze CK, Horstrup JH, Warnecke C, Mandriota S, Bechmann I, Frei UA, Pugh CW, Ratcliffe PJ, Bachmann S, Maxwell PH, Eckardt KU: Widespread hypoxia-inducible expression of HIF-2alpha in distinct cell populations of different organs. FASEB J 2003;17:271-273. 


\section{Cellular Physiology and Biochemistry}

Cell Physiol Biochem 2014;34:1427-1441

Cao et al.: HIF-2 $\alpha$ Regulates Lipid Metabolism

-39 Wiesener MS, Turley H, Allen WE, Willam C, Eckardt KU, Talks KL, Wood SM, Gatter KC, Harris AL, Pugh CW, Ratcliffe PJ, Maxwell PH: Induction of endothelial PAS domain protein-1 by hypoxia: characterization and comparison with hypoxia-inducible factor-1alpha. Blood 1998;92:2260-2268.

40 Wada T, Shimba S, Tezuka M: Transcriptional regulation of the hypoxia inducible factor-2alpha (HIF2alpha) gene during adipose differentiation in 3T3-L1 cells. Biol Pharm Bull 2006;29:49-54.

-41 Hu CJ, Wang LY, Chodosh LA, Keith B, Simon MC: Differential roles of hypoxia-inducible factor 1alpha (HIF1alpha) and HIF-2alpha in hypoxic gene regulation. Mol Cell Biol 2003;23:9361-9374.

-42 Guillet-Deniau I, Pichard AL, Kone A, Esnous C, Nieruchalski M, Girard J, Prip-Buus C: Glucose induces de novo lipogenesis in rat muscle satellite cells through a sterol-regulatory-element-binding-protein-1cdependent pathway. J Cell Sci 2004;117:1937-1944.

43 Shimomura I, Bashmakov Y, Horton JD: Increased levels of nuclear SREBP-1c associated with fatty livers in two mouse models of diabetes mellitus. J Biol Chem 1999;274:30028-30032.

-44 Li J, Grigoryev DN, Ye SQ, Thorne L, Schwartz AR, Smith PL, O'Donnell CP, Polotsky VY: Chronic intermittent hypoxia upregulates genes of lipid biosynthesis in obese mice. J Appl Physiol (1985) 2005;99:1643-1648.

45 Li J, Thorne LN, Punjabi NM, Sun CK, Schwartz AR, Smith PL, Marino RL, Rodriguez A, Hubbard WC, O'Donnell CP, Polotsky VY: Intermittent hypoxia induces hyperlipidemia in lean mice. Circ Res 2005;97:698-706.

-46 Parathath S, Mick SL, Feig JE, Joaquin V, Grauer L, Habiel DM, Gassmann M, Gardner LB, Fisher EA: Hypoxia is present in murine atherosclerotic plaques and has multiple adverse effects on macrophage lipid metabolism. Circ Res 2011;109:1141-1152.

47 Manalo DJ, Rowan A, Lavoie T, Natarajan L, Kelly BD, Ye SQ, Garcia JG, Semenza GL: Transcriptional regulation of vascular endothelial cell responses to hypoxia by HIF-1. Blood 2005;105:659-669.

48 Cao R, Hu Y, Wang Y, Gurley EC, Studer EJ, Wang X, Hylemon PB, Pandak WM, Sanyal AJ, Zhang L, Zhou H: Prevention of HIV protease inhibitor-induced dysregulation of hepatic lipid metabolism by raltegravir via endoplasmic reticulum stress signaling pathways. J Pharmacol Exp Ther 2010;334:530-539.

49 Colgan SM, Hashimi AA, Austin RC: Endoplasmic reticulum stress and lipid dysregulation. Expert Rev Mol Med 2011;13:e4.

50 Lee AH, Glimcher LH: Intersection of the unfolded protein response and hepatic lipid metabolism. Cell Mol Life Sci 2009;66:2835-2850.

51 Zheng Z, Zhang C, Zhang K: Role of unfolded protein response in lipogenesis. World J Hepatol 2010;2:203207. 